\title{
ANALISA KADAR LEMAK, PATI, GULA REDUKSI, MINERAL (Fe, Ca, Na dan Mg) PELET IKAN DARI LIMBAH ORGANIK
}

\author{
Hasmalina Nasution, Winda Deliani, Isnaniar, Wahyunungsih
}

Prodi. Kimia, Fakultas MIPA dan Kesehatan, Universitas Muhammadiyah Riau email: hasmalinanst@umri.ac.id

\begin{abstract}
ABSTRAK
Budidaya ikan di Indonesia merupakan salah satu komponen yang penting pada sektor perikanan. Ikan yang dibudidayakan memerlukan pakan berkualitas dengan kandungan nutrisi yang lengkap agar dapat hidup dan berkembang biak dengan baik. Mahalnya harga pakan dapat diatasi salah satunya dengan membuat pakan buatan sendiri menggunakan metode yang sederhana. Penelitian ini bertujuan untuk mengetahui pengaruh fermentasi pelet ikan yang dibuat dari limbah organik (bekicot, tulang ikan lele, kulit pisang dan kulit singkong) terhadap nilai kadar lemak, pati, gula reduksi dan mineral dengan variasi waktu $0,1,2,3,4$ dan 5 hari. Mikroorganisme yang digunakan untuk fermentasi adalah Saccharomyces cerevisiae dalam keadaan aerob. Analisis kadar lemak digunakan metode soxhlet dan didapatkan waktu optimal kadar air adalah pada hari ke 3 yaitu 11,18\%. Analisis kadar pati dan gula reduksi menggunakan metode iodometri dan didapatkan waktu optimal kadar pati dan gula reduksi pada hari ke 3 yaitu 9,06\% dan 10,07\% dan analisis mineral digunakan metode spektrofotometri serapan atom (SSA) dan didapatkan waktu optimal terhadap kadar mineral adalah pada hari ke 2 yaitu 1039 mg/kg Ca, 44,63 mg/kg Na, 20,76 mg/kg Mg dan $150,98 \mathrm{mg} / \mathrm{kg}$ Fe. Hasil uji $\mathrm{t}(\mathrm{p}=0,05)$ menunjukkan tidak adanya perbedaan nyata antara hasil kadar lemak, pati dan gula reduksi yang diperoleh antara waktu fermentasi 4 dan 5 hari. Pelet ikan yang difermentasi pada waktu optimal (3 hari) untuk lemak memenuhi syarat mutu pakan ikan patin SNI 7548:2009 yaitu kadar lemak maksimal $14 \%$.
\end{abstract}

Kata kunci: Pelet ikan, Kadar lemak, Kadar pati, Kadar gula reduksi, Mineral

\section{PENDAHULUAN}

Indonesia merupakan negara dengan didukung oleh wilayah perairan yang sangat luas, meliputi 11,95 juta (Ha) sungai dan rawa, 1,87 juta (Ha) danau alam, 0,003 (Ha) danau buatan serta perairan laut yang luas, telah memberikan kemudahan bagi masyarakat khususnya petani ikan untuk mengembangkan usaha perikanan di Indonesia (Raflie, 2007).

Pakan atau makanan merupakan unsur penting dalam budidaya ikan, pakan yang diberikan harus memenuhi standar nutrisi (gizi) bagi ikan agar kelangsungan hidupnya tinggi dan pertumbuhannya cepat. Pakan yang baik memiliki komposisi zat gizi yang lengkap seperti protein, lemak, karbohidrat, vitamin dan mineral (Cahyono,2001). Pakan ikan yang sering dijumpai dipasaran berupa pelet.

Pelet adalah bentuk makanan buatan yang dibuat dari beberapa macam bahan yang kita ramu dan jadikan adonan, kemudian kita cetak berbentuk batangan atau bulatan kecil-kecil. Ukuran berkisar antara 1-2cm. Pelet tidak berupa tepung, tidak berupa butiran, dan tidak pula berupa larutan (Setyono, 2012). Permasalahan yang sering terjadi menjadi kendala adalah penyediaan pakan buatan ini memerlukan biaya yang relatif tinggi, bahkan mencapai $60-70 \%$ dari komponen biaya produksi (Emma, 2006).

Pada umumnya harga pakan ikan yang terdapat di pasaran relatif mahal. Adapun alternatif pemecahan yang dapat diupayakan adalah dengan membuat pakan buatan sendiri melalui teknik yang sederhana dengan memanfaatkan sumber-sumber bahan baku yang relatif murah. Bahan baku yang digunakan harus memiliki kandungan nilai gizi yang baik yaitu yang mudah didapat ketika diperlukan, mudah diolah dan diproses, mengandung zat gizi yang diperlukan oleh ikan dan berharga murah.

Bahan alternatif yang murah dan mudah didapat salah satunya adalah limbah organik. Limbah adalah buangan yang dihasilkan dari suatu proses produksi baik industri maupun domestik (rumah tangga), yang kehadirannya pada suatu saat dan tempat tertentu tidak dikehendaki lingkungan karena tidak memiliki nilai ekonomis. Bila ditinjau secara kimiawi, limbah ini terdiri dari bahan kimia senyawa organik dan senyawa anorganik. Kehadiran 
limbah pada konsentrasi dan kuantitas tertentu dapat berdampak negatif terhadap lingkungan terutama bagi kesehatan manusia, sehingga perlu dilakukan penanganan terhadap limbah (Widjajanti, 2009). Berdasarkan teknologi yang sudah ada, pengkayaan bahan pakan berasal dari limbah dengan memanfaatkan bahan kimia maupuns secara mikrobiologi secara tidak langsung dapat digunakan sebagai bahan pakan hewan (Wiyatno dkk, 2010).

Bahan baku utama dalam pembuatan ransum pakan buatan yang umumnya dipakai adalah tepung ikan dengan kandungan nutrisi menurut Gusrina (2008) adalah protein $62,65 \%$, lemak $6,5 \%$ dan karbohidrat $8,5 \%$, akan tetapi bahan baku utama pada pakan buatan dapat juga menggunakan bahan baku yang lain seperti tepung daging bekicot sebagai bahan baku pakan, sangat dominan dimanfaatkan untuk pengganti bahan baku tepung ikan dalam ransum pakan karena diketahui memiliki nutrisi yang sebanding dengan tepung ikan. Sahwan (2002) menyatakan bahwa kandungan nutrisi pada tepung daging bekicot adalah protein berkisar antara 54,29$64,14 \%$, lemak $3,92-4,18 \%$, karbohidrat 30,45\%. Menurut Murtidjo (1987) menyatakan bahwa penggunaan tepung daging bekicot optimum dalam penyusunan pakan buatan hingga $25 \%$.

Pisang merupakan salah satu komoditi perkebunan di Indonesia yang banyak dibudidayakan. Kulit pisang merupakan bahan buangan (limbah buah pisang) yang cukup banyak jumlahnya. Pada umumnya kulit pisang belum dimanfaat secara nyata, hanya dibuang sebagai limbah organik atau digunakan sebagai makanan ternak. (Susanti, 2006).

Menurut Basse (2000) menyatakan bahwa kandungan unsur gizi kulit pisang cukup lengkap, seperti karbohidrat, lemak, protein, kalsium, fosfor, zat besi, vitamin B dan vitamin C. Hasil analisis kimia menunjukkan bahwa komposisi kulit pisang banyak mengandung air yaitu $68,90 \%$ dan karbohidrat sebesar $18,50 \%$.

Kulit singkong merupakan limbah dari pengupasan umbi singkong. Secara umum kulit singkong ini hanya dibiarkan membusuk untuk dijadikan pupuk dan hanya sebagian kecil yang dimanfaatkan sebagai pakan. Potensi singkong di Indonesia sangatlah besar. BPS (2008) yakni sebesar 20.794.929 ton. Setiap singkong menghasilkan kulit singkong sebesar $16 \%$ dari berat totalnya. Kandungan dalam kulit singkong mengandung karbohidrat sebesar 74,73\% (Pratiwi, 2013).

Pada pembuatan pelet diharapkan menghasilkan pelet yang memiliki kandungan gizi yang tinggi. Salah satu cara untuk meningkatkan kandungan gizi adalah fermentasi. Proses fermentasi dapat meningkatkan kadar protein (Fransistika dkk, 2012), menurunkan kadar serat kasar (Utami dkk, 2012), menurunkan kadar HCN yang terdapat pada kulit singkong (Pratiwi, 2013) dan sebagai produksi gas $\mathrm{CO}_{2}$ (Yaumi, 2010) pada pelet agar dapat mengapung. Produksi protein dengan fermentasi menggunakan pembaharuan bahan meliputi limbah organik telah mendapatkan perhatian dari dunia sebagai solusi pemanfaatan limbah lingkungan maupun industri (Wiyatno dkk, 2010).

\section{METODOLOGI PENELITIAN Teknik Analisa dan Pengumpulan Data}

Penelitian yang akan dilakukan adalah pembuatan pelet ikan dari campuran limbah kulit pisang, kulit singkong, tulang ikan, dan daging bekicot yang semua bahan campuran telah di jadikan tepung dengan fermentasi yaitu 30 gram tepung bekicot $+22,5$ gram tepung ikan lele + 22,5 gram tepung bekicot $+7,5$ gram tepung kulit singkong $+0,75$ gram ragi roti. Pembuatan pelet ikan dilakukan dengan memvariasikan lama fermentasi yaitu $0,1,2,3,4$ dan 5 hari dari limbah kulit pisang, kulit singkong, daging bekicot dan tulang ikan lele. Setelah proses fermentasi dilakukan analisis pati, gula reduksi, lemak dan mineral makro ( $\mathrm{Ca}, \mathrm{Mg}, \mathrm{Na}$ dan $\mathrm{Fe}$ ) pada pelet ikan yang dihasilkan dan dilakukan analisis data.

\section{Alat dan Bahan}

Alat

Alat yang digunakan dalam proses pembuatan pelet ikan adalah oven, panci presto, blender, ayakan, pencetak pelet dan wadah. Alat yang digunakan untuk analisa pelet adalah kertas saring, Erlenmeyer, labu, alat soxhlet, pemanas 
listrik, oven, neraca analitik, kapas, kaca arloji, gelas piala, desikator, vurnes, seperangkat alat SSA (PerkinElmer Analyst 200), dan pipet volum.

\section{Bahan}

Bahan yang digunakan dalam proses pembuatan pelet ikan adalah bekicot, tulang ikan lele, ragi roti, kulit singkong, kulit pisang dan air bersih.

Bahan yang digunakan dalam proses analisa pelet ikan adalah larutan standar, $\mathrm{HNO}_{3}$ pekat, $\mathrm{HCl} 3 \%, \mathrm{H}_{2} \mathrm{SO}_{4}$ pekat, air suling, larutan indikator, larutan $\mathrm{NaOH} 30 \%, \mathrm{HCl} 0,1 \mathrm{~N}, \mathrm{n}$ heksan, $\mathrm{Na}_{2} \mathrm{CO}_{3} 10 \%, \mathrm{CH}_{3} \mathrm{COOH} 3 \%$, larutan luff, KI 20\% dan larutan tiosulfat.

\section{Prosedur Pembuatan Pelet Ikan \\ Pembuatan Tepung Bekicot (Suharto, 1999)}

Bekicot direndam dengan air garam 1\% selama 30 menit dan dagingnya dikeluarkan dari cangkangnya lalu dicuci sampai bersih dengan air bersih. Dikeringkan dalam oven selama 12 jam pada suhu $60^{\circ} \mathrm{C}$ kemudian ditepungkan dan diayak.

Pembuatan Tepung Tulang Ikan Lele (Pratomo dkk, 2010)

Tulang ikan dicuci bersih dengan air bersih. Tulang ikan dikukus selama 10 menit dan dicuci lagi jika masih ada sisa daging yang menempel. Direbus pada suhu $100^{\circ} \mathrm{C}$ selama 30 menit dan dipotong-potong $\pm 5 \mathrm{~cm}$. Dimasak menggunakan panci presto sampai matang dan dilanjutkan lagi hingga 2 jam dengan api kecil. Dioven pada suhu $120^{\circ} \mathrm{C}$ selama 35 menit. Ditepungkan dan diayak.

\section{Pembuatan Tepung Kulit Pisang (Zuhrina, 2011)}

Kulit pisang dibersihkan dan dicuci lalu dipotong kecil-kecil. Direndam dalam air bersih dan dikeringkan dibawah sinar matahari \pm 4 hari. Kulit pisang kering ditepungkan dan diayak.

Pembuatan Tepung Kulit Singkong (Pratiwi, 2013)

Kulit singkong dibersihkan dari kulit bagian luar yang berwarna coklat dan dicuci bersih. Kulit singkong dipotong-potong dan dibalur dengan abu dapur kering dan diletakkan dalam tempat terbuat dari anyaman bambu dan ditutup daun pisang lalu dibiarkan selama 24 jam. Setelah 24 jam, kulit singkong dicuci dengan air bersih dan direndam dengan air selama 48 jam dan 3 jam sekali air diganti. Ditiriskan dan direndam dalam air mendidih selama 3-5 menit. Kemudian ditiriskan dan di jemur selama 4-5 hari dan ditepungkan dan diayak.

\section{Pembuatan dan Fermentasi Pelet Ikan}

Disiapkan enam wadah yang sudah diberi label 0 - 5 hari dan setiap wadah dimasukkan tepung bekicot $30 \mathrm{gr}$, tepung tulang ikan lele 25 gr, dan tepung kulit pisang 25 gr. Setiap wadah ditambahkan tepung kulit singkong 20 gr yang telah dicairkan dalam air mendidih hingga membentuk seperti lem. Semua bahan diuleni pada setiap wadah hingga elastis. Pada setiap wadah dimasukkan ragi roti $1 \%$ dan diuleni lagi. Kemudian ditutup menggunakan daun pisang (proses fermentasi aerob). Pada wadah yang berlabel 0 hari langsung dicetak menggunakan mesin pencetak pelet atau dibentuk sendiri dengan cara dipilin dengan diameter 3 - $6 \mathrm{~mm}$ dan panjang $1-2 \mathrm{~cm}$. Pada wadah yang berlabel 1 hari, dicetak setelah satu hari fermentasi dan begitu pula pada pelet ikan pada fermentasi 2 - 5 hari.

Prosedur Analisa Pelet (SNI-01-28911992)

\section{Analisa Kadar Lemak}

4 gr sampel yang telah dihaluskan, diekstrak dengan petroleum eter dalam alat soxhlet bersama batu didih. Ekstraksi dilakukan selama 6 jam. Lemak yang telah diekstraksi disuling, lemak dan sisa petroleum eter dikeringkan pada temperature $100^{\circ} \mathrm{C}$ selama 1 jam. Didinginkan dalam desikator, ditimbang.

\section{Analisa Glukosa ( Hidrolisa Pati)}

0,5 gr pati dimasukkan ke dalam gelas beaker, ditambahkan $5 \mathrm{ml}$ aquades dan dipanaskan pada suhu $72-90^{\circ} \mathrm{C}$, ditambahkan 10 $\mathrm{ml}$ HCL 3\% dipanaskan dipenangas air selama 2 jam. Didinginkan pada suhu kamar dan dinetalkan dengan $\mathrm{Na}_{2} \mathrm{CO}_{3} \quad 10 \%$ dan disaring diambil filtratnya sebagai hasil hidrolisa. Pengukuran panjang gelombang maksimum 530$550 \mathrm{~nm}$. Ditimbang $20 \mathrm{mg}$ glukosa anhidrat dengan aquadest sampai volume $100 \mathrm{ml}$, dipipet 25 ml larutan diatas dan diencerkan dengan aquadest dalam labu takar $100 \mathrm{ml}$. Dipipet $1 \mathrm{ml}$ 
larutan glukosa $0,05 \mathrm{mg} / \mathrm{ml}$ kemudian ditambah $1 \mathrm{ml}$ pereaksi nelson dan didinginkan hingga suhu mencapai $25^{\circ} \mathrm{C}$. Ditambahkan $0,5 \mathrm{ml}$ larutan arsenomolibdat dikocok hingga endapan $\mathrm{Cu}_{2} \mathrm{O}$ larut sempurna. Diukur panjang gelombang pada $530-550 \mathrm{~nm}$.

\section{Analisa Kadar Mineral (Ca, Na, Mg dan Fe)}

5 gr sampel dikeringkan pada suhu 100$105^{\circ} \mathrm{C}$, setelah kering dimasukkan ke dalam tanur pada suhu $1000^{\circ} \mathrm{C}$ sehingga diperoleh abu. Abu yang diperoleh didestruksi dengan $\mathrm{HNO} 3$ (p) hingga larut. Larutan tersebut diencerkan dalam labu takar $100 \mathrm{ml}$ hingga tanda batas, larutan dianalisa dengan menggunakan Spektrofotometri Serapan Atom (SSA)

\section{HASIL DAN PEMBAHASAN Hasil Pengamatan}

Hasil penelitian ini adalah nilai kadar lemak, pati, gula reduksi dan mineral makro ( $\mathrm{Na}, \mathrm{Mg}$, $\mathrm{Ca}$, dan $\mathrm{Fe}$ ) pada pelet ikan dari limbah organik yaitu daging bekicot, kulit pisang, tulang ikan lele, dan kulit singkong dengan perbandingan 4: 3: 3 yang difermentasi dengan ragi roti (Saccharomyces cerevisiae) secara aerob pada variasi waktu $0,1,2,3,4$ dan 5 hari. Pelet ikan pada penelitian ini juga dibuat tanpa fermentasi (0 hari) dan ragi roti (Saccharomyces cerevisiae). Hal ini bertujuan untuk mengetahui pengaruh penambahan ragi roti dalam pelet ikan. Hasil yang didapatkan dari masing-masing analisa adalah sebagai berikut

Tabel 4.1. Hasil Analisa Pelet Ikan

\begin{tabular}{|c|c|c|c|c|c|c|c|}
\hline \multicolumn{8}{|c|}{ Hasil Analisa Pelet Ikan Fermentasi } \\
\hline \multirow[b]{2}{*}{$\begin{array}{c}\text { Waktu } \\
\text { Fermentasi } \\
\quad \text { (hari) }\end{array}$} & arat & 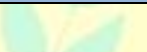 & & Parameter & & 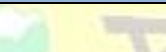 & \\
\hline & $\begin{array}{c}\text { Kadar } \\
\text { Lemak } \\
(\%)\end{array}$ & $\begin{array}{c}\text { Kadar } \\
\text { Pati }(\%)\end{array}$ & $\begin{array}{c}\text { Kadar } \\
\text { Gula } \\
\text { Reduksi } \\
(\%)\end{array}$ & $\begin{array}{c}\text { Kadar } \\
\text { Mineral } \\
\mathrm{Ca} \\
(\mathrm{mg} / \mathrm{kg}) \\
\end{array}$ & $\begin{array}{c}\text { Kadar } \\
\text { Mineral } \\
\mathrm{Na} \\
(\mathrm{mg} / \mathrm{kg}) \\
\end{array}$ & $\begin{array}{c}\text { Kadar } \\
\text { Mineral } \\
\text { Fe } \\
(\mathrm{mg} / \mathrm{kg}) \\
\end{array}$ & $\begin{array}{c}\text { Kadar } \\
\text { Mineral } \\
\mathrm{Mg} \\
(\mathrm{mg} / \mathrm{kg})\end{array}$ \\
\hline 0 & 11,70 & 13,82 & 15,36 & 803,34 & 41,98 & 138,26 & 19,57 \\
\hline 1 & 10,73 & 9,64 & 10,66 & 945,05 & 40,48 & 139,04 & 19,79 \\
\hline 2 & 10,10 & 7,91 & 8,79 & 1039,00 & 44,63 & 150,98 & 20,76 \\
\hline 3 & 11,18 & 9,06 & 10,07 & 1011,22 & 39,09 & 126,60 & 19,67 \\
\hline 4 & 9,86 & 7,79 & 8,67 & 973,06 & 39,39 & 121,17 & 19,85 \\
\hline 5 & 9,80 & 8,25 & 9,17 & 868,17 & 32,46 & 123,40 & 20,13 \\
\hline \multicolumn{8}{|c|}{ Hasil Analisa Pelet Ikan Tanpa Fermentasi dan Tanpa Ragi Roti } \\
\hline $\begin{array}{c}\text { Tanpa } \\
\text { Fermentasi }\end{array}$ & 11,96 & 14,51 & 16,12 & 984,79 & 40,54 & 14 & 71 \\
\hline
\end{tabular}

\section{Pembahasan}

Pada penelitian ini digunakan sampel pelet ikan hasil fermentasi limbah organik yang terdiri dari bekicot, tulang ikan lele, kulit pisang dan kulit singkong yang telah dijadikan tepung. Fermentasi limbah organik ini dilakukan dalam wadah yang berbeda dengan perlakuan dan komposisi yang sama dengan variasi waktu 0,1 , 2, 3, 4 dan 5 hari menggunakan ragi roti (Saccharomyces cerevisiae) secara aerob. Pelet yang telah dihasilkan dilakukan analisa kadar lemak, pati, gula reduksi dan mineral makro (Fe, $\mathrm{Na}, \mathrm{Mg}$ dan $\mathrm{Ca}$ ).

\section{Analisa Kadar Lemak}

Lemak mengandung karbon, hidrogen dan oksigen. Namun lemak mengandung lebih banyak karbon dan hidrogen daripada oksigen. Lemak memberikan 2,25 kali lebih banyak energi daripada karbohidrat. Lemak dalam pakan ikan berfungsi sebagai sumber energi, sumber lemak esensial, fosfolipid, sterol dan pengantar vitamin yang terlarut di dalamnya, yaitu vitamin A, D, K dan E, selain itu lemak juga membantu dalam pembuatan pakan ikan dalam bentuk pellet (Murtidjo, 2001).

Pada hasil penelitian ini menunjukkan bahwa kandungan lemak pada pakan ikan 
sebelum ditambahkan ragi roti dan fermentasi sebesar 11,96\% sedangkan setelah ditambahkan ragi roti mengalami penurunan menjadi $11,71 \%$. Hal ini di karenakan di dalam ragi roti yang digunakan mengandung lemak sebesar 4-5\%. Pada hasil kandungan lemak dalam pelet ikan tersebut mengalami penurunan setelah fermentasi sampai hari ke 2 dan mengalami kenaikan pada hari ke 3 sebesar 11,18\%. Kadar lemak yang didapatkan pada penelitian ini telah memenuhi ketentuan standar SNI. Lemak dalam pakan berpengaruh terhadap rasa dan tekstur pakan. Menurut Mudjiman (2004) bahwa kandungan lemak ideal untuk pakan ikan berkisar 4-18\%.

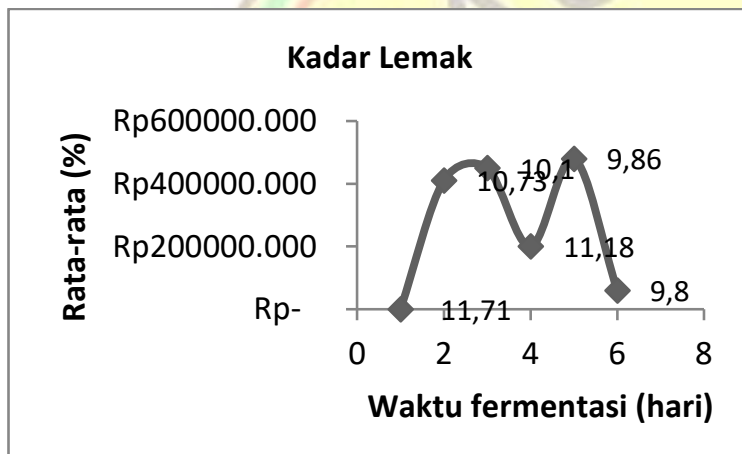

Grafik Hasil Kadar Lemak Pelet Ikan

Pakan yang mengandung hasil fermentasi memiliki kandungan gizi yang lebih baik dan mudah dicerna serta diserap oleh tubuh ikan. Hampir semua lemak dalam pakan ikan dapat dicerna. Pakan yang mengandung lemak yang tinggi akan mempengaruhi pertumbuhan ikan. Pada penelitian ini mengalami peningkatan kandungan lemak pada waktu fermentasi 3 hari. Peningkatan kandungan lemak tersebut diduga disebabkan oleh lamanya waktu fermentasi yang dapat memberikan kesempatan pada S. cerevisiae untuk tumbuh dan berkembang sehingga akan meningkatnya massa mikrobial yang kaya lemak.

Pembuktian waktu optimal pada fermentasi pelet ikan terhadap kadar lemak diuji secara statistik menggunakan uji $t$ pada waktu fermentasi pelet ikan 4 dan 5 hari. Hal ini dilakukan karena antara waktu 4 dan 5 hari selisihnya dekat. Setelah dilakukan uji t ternyata tidak terjadi perbedaan yang nyata pada $p=0,05$.

Kandungan lemak yang tinggi memerlukan proses penyimpanan yang baik, jika tidak maka akan mempercepat terjadi ketengikan yang dapat merusak nutrisi yang terdapat pada pakan ikan. Menurut wulandari (2000) ketengikan disebabkan oleh enzim proteolitik menjadi aktif, enzim ini yang menyebabkan kandungan lemak bebas dari minyak naik dengan cepat.

\section{Analisa Kadar Pati}

Pati merupakan elemen yang terakhir dalam proses pertumbuhan ikan karena kemampuan ikan untuk dapat mencerna pati sangat rendah. Kebutuhan pati dalam ikan relatif sedikit dan cenderung dimanfaatkan sebagai kerangka karbon untuk sintesis protein (Tacon, 1987). Pada hasil penelitian yang didapatkan bahwa kandungan pati yang terdapat dalam pakan ikan tersebut mengalami penurunan dari hari ke 0 sampai hari ke 2 dan mengalami kenaikan pada hari ke 3 sebesar 9,06\%. Hasil kandungan pati mengalami penurunan pada hari ke 0 sampai hari ke 2 hal ini menunjukkan bahwa pati mengalami hidrolisis oleh enzim amilase yang dihasilkan dari s. cerevisae (Satyawiharja, 1984). Dan pati sebagai sumber energi utama selama proses fermentasi sehingga kandungan pati dalam pakan rendah.

Wilson (1994) melaporkan bahwa ikan yang diberi pakan tanpa kandungan pati memiliki laju pertumbuhan yang relatif rendah dibandingkan pakan yang memiliki kandungan pati. Pemberian pati yang tinggi akan mengakibatkan pertumbuhan ikan menurun. Kadar kandungan pati dalam pakan ikan untuk benih hewan omnivora sebesar $20 \%$ dan sedangkan untuk benih hewan karnivora sebesar 30\% (Furuichi, 1988). Hasil menunjukkan pada penelitian ini bahwa kandungan pati dalam pakan ikan buatan ini masih dalam batas yang dapat dicerna dengan baik oleh ikan. Sumber karbohidrat seperti pati dapat digunakan sebagai perekat dalam pakan ikan dan udang untuk meningkatkan ketahanan pakan di air (Millamena et al, 2002). 


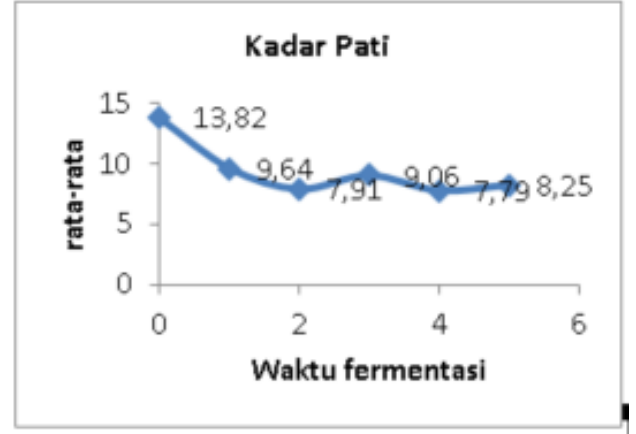

Grafik Hasil Kadar Pati Pelet Ikan

Adapun metode yang digunakan pada uji kadar pati menggunakan metode Luff dalam penelitian ini. Metode Luff yaitu metode yang menghidrolisis karbohidrat menjadi gula pereduksi untuk dapat mereduksi $\mathrm{CuO}$. Kelebihan $\mathrm{CuO}$ direduksi dengan $\mathrm{KI}$ yang melepaskan $\mathrm{I}_{2}$ yang bebas dalam keadaan asam, kemudian $\mathrm{I}_{2}$ akan dititrasi oleh $\mathrm{Na}_{2} \mathrm{~S}_{2} \mathrm{O}_{3}$.

\section{Analisa Kadar Gula Reduksi}

Gula reduksi merupakan hasil dari proses hidrolisis pati. Hasil analisa kadar gula reduksi pelet ikan menunjukkan penurunan kadar gula reduksi sampai hari ke 2 fermentasi yaitu sebesar $8,79 \%$ dan mengalami kenaikan kadar gula reduksi pada hari ke 3 fermentasi sebesar $10,07 \%$. Kadar gula reduksi pelet ikan sebelum ditambahkan ragi roti dan fermentasi adalah $16,12 \%$ sedangkan setelah penambahan ragi roti mengalami penurunan kadar gula reduksi sebesar $15,36 \%$.

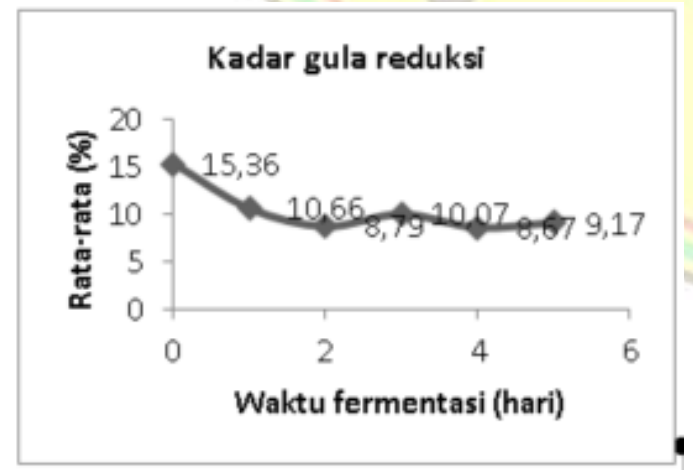

Grafik Hasil Kadar Gula Reduksi Pelet Ikan

Proses fermentasi dapat menurunkan kadar gula reduksi bahan yang difermentasi. Tinggi rendahnya selisih penurunan kadar gula reduksi pada bahan tergantung jenis bakteri atau khamir yang digunakan (Ginting dan Krisnan, 2006). Dalam penelitian ini penurunan kadar gula reduksi akibat fermentasi berhenti pada hari ke 2 fermentasi dan merupakan waktu optimal kadar gula reduksi pelet ikan dalam fermentasi penelitian ini.

\section{Analisa Kadar Mineral}

Mineral merupakan komponen pakan yang sangat dibutuhkan yaitu sebagai pembentukkan struktur rangka dan sisik. Kebutuhan ikan akan mineral dapat berbeda tergantung jenis ikannya. Mineral dibagi dua bagian yaitu makro mineral dan mikro mineral. Makro mineral yaitu mineral yang dibutuhkan dalam tubuh setiap organisme dalam jumlah yang cukup besar. Sedangkan mineral mikro yaitu mineral yang dibutuhkan dalam tubuh setiap organisme dalam jumlah yang sedikit. Kadar abu pada pakan menunjukkan indikator besarnya kandungan mineral yang terdapat dalam pakan tersebut (Jangkaru, 1974). Peningkatan kadar abu disebabkan adanya penambahan mineral pada proses fermentasi. Menurut Kamal (1994), bahwa aktivitas mikroba juga bisa menyebabkan peningkatan kadar abu. Kadar abu yang tinggi sangat menentukan kandungan mineral yang tinggi dalam pakan ikan. Hasil penelitian yang telah dilakukan oleh Nike (2015), bahwa waktu optimal kadar abu yang didapatkan pada penelitian pakan ikan sebesar $14,46 \%$. Hal ini menunjukkan bahwa besarnya kandungan kadar abu dalam pakan ikan menetukan besarnya nilai kandungan kadar mineral dalam pakan ikan tersebut. Mineral dibutuhkan oleh ikan dalam proses pertumbuhannya. Makro mineral meliputi $\mathrm{Ca}$ (kalsium), $\mathrm{Mg}$ (magnesium), $\mathrm{Na}$ (natrium) yang dibutuhkan dalam jumlah yang banyak sebesar > $100 \mathrm{mg} / \mathrm{kg}$ dalam pakan ikan kering (Sahwan, 2002). Kalsium (Ca) diperlukan untuk pembentukkan tulang dan untuk menjaga fungsi jaringan tubuh agar dapat bekerja secara normal. Pada hasil yang di dapatkan dalam penelitian ini kandungan kadar $\mathrm{Ca}$ dalam pakan ikan buatan sebelum ditambahkan ragi roti dan fermentasi sebesar 984,79 $\mathrm{mg} / \mathrm{kg}$ sedangkan setelah ditambahkan ragi roti dan fermentasi mengalami 
penurunan kadar $\mathrm{Ca}$ dalam pakan ikan buatan tersebut sebesar 803,34 mg/kg. Hasil kadar mineral Ca yang didapat besar dari $100 \mathrm{mg} / \mathrm{kg}$. Tingginya kadar kalsium pada pelet ikan ini disebabkan oleh tinggi kandungan kalsium dalam bahan-bahan pembuatan pelet ikan tersebut. Hal tersebut yang menyebabkan kadar kalsium (Ca) dalam pelet ikan tinggi.

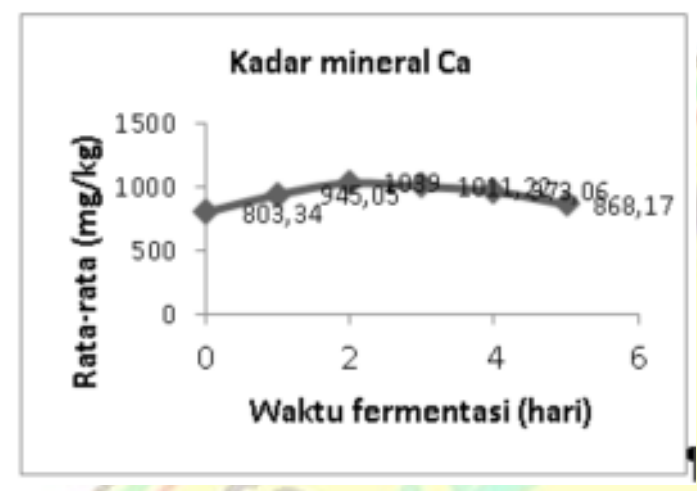

Grafik Kadar Mineral Ca Pelet Ikan

Untuk hasil kadar mineral $\mathrm{Na}$ dan $\mathrm{Mg}$ pada penelitian ini dapat dilihat pada gambar grafik 4.5 yang mengalami kenaikan sampai hari ke 2 fermentasi dan mengalami penurunan pada hari ke 3 sampai hari ke 5 fermentasi. Hasil yang didapatkan pada kandungan mineral $\mathrm{Na}$ dan $\mathrm{Mg}$ tidak memenuhi batas minimum gizi dalam pakan ikan buatan tersebut karena kandungan yang didapatkan dibawah $100 \mathrm{mg} / \mathrm{kg}$ dalam pakan ikan buatan kering.

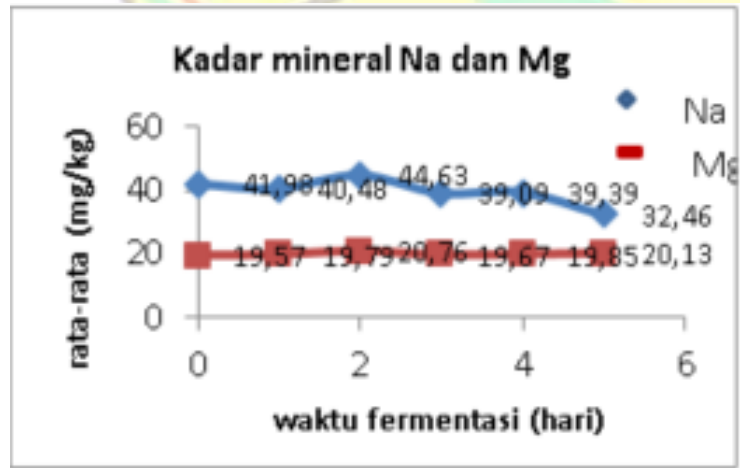

Grafik Kadar Mineral Na dan Mg Pelet Ikan

Mineral mikro meliputi Fe (besi), Zn (seng), I (iodine) dan lain-lain. Kandungan mineral mikro dalam pakan ikan buatan yang diperbolehkan adalah $<100 \mathrm{mg} / \mathrm{kg}$ dalam pakan ikan kering (Sahwan, 2002). Besi (Fe) diperlukan untuk pembentukkan sel darah merah. Pada penelitian ini didapatkan hasil kandungan mineral $\mathrm{Fe}$ sebelum ditambahkan ragi roti dan fermentasi sebesar $136,10 \mathrm{mg} / \mathrm{kg}$, sedangkan setelah ditambahkan ragi roti dan fermentasi mengalami kenaikan sebesar 138,26 mg/kg. Hasil setelah ditambahkan ragi roti dan fermentasi mengalami kenaikan dari fermentasi 0 hari sampai 2 hari fermentasi sebesar 150,98 mg/kg dan mengalami penurunan dari hari ke 3 fermentasi sampai hari ke 4 fermentasi sebesar $126,60 \mathrm{mg} / \mathrm{kg}$ dan $121,17 \mathrm{mg} / \mathrm{kg}$. Hasil pada penelitian ini didapatkan melebihi batas yang diperbolehkan dalam pakan ikan kering.

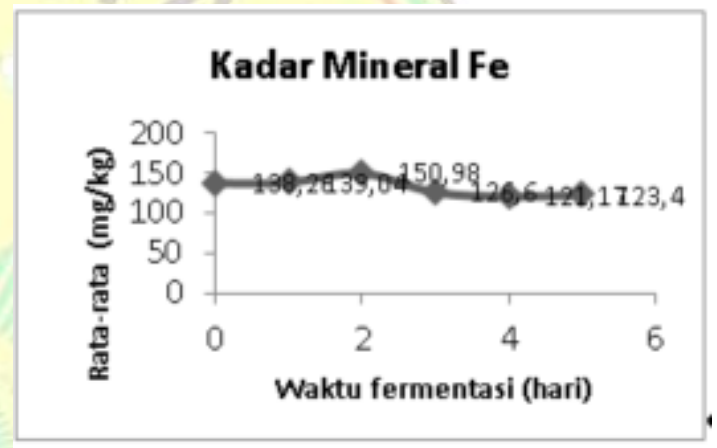

Grafik Kadar Mineral Fe Pelet Ikan

\section{KESIMPULAN DAN SARAN}

\section{Kesimpulan}

Berdasarkan hasil penelitian ini diperoleh kesimpulan sebagai berikut:

1. Dari hasil analisa yang didapatkan nilai tertinggi untuk uji kadar mineral terdapat pada hari kedua fermentasi dan untuk uji kadar (lemak, pati dan gula reduksi) terdapat pada hari ke tiga fermentasi.

2. Waktu fermentasi mempengaruhi hasil pengukuran kadar lemak, pati, gula reduksi, dan mineral ( $\mathrm{Fe}, \mathrm{Na}, \mathrm{Ca}$ dan $\mathrm{Mg}$ ).

\section{Saran}

Berdasarkan penelitian yang dilakukan saran yang dapat disampaikan adalah sebagai berikut:

1. Perlu dicoba fermentasi menggunakan mikroorganisme anaerob.

2. Variasi waktu fermentasi perlu dicoba dengan selisih waktu yang lebih dekat.

3. Saccharomyces cerevisiae yang digunakan adalah Saccharomyces cerevisiae murni. 


\section{DAFTAR PUSTAKA}

Abun., 2004. Pengaruh Cara Pengolahan Limbah Ikan Tuna Terhadap Kandungan Gizi dan Nilai Energi Metabolisme pada Ayam Pedaging. Laporan Penelitian: Universitas Padjajaran, Bandung.

Afrianto,E dan Liviawaty., 2005. Pakan Ikan. Penerbit Kanisius, Yogyakarta.

Arie, P.L. 2003. Pembuatan Brem Ketan Hitam

(Kajian Penambahan Air Tape Ketan Putih dan Bahan Pengembang Terhadap Sifat Fisik, Kimia dan Organoleptik). Skripsi. FTP, UB. Malang.

Asa, K., 1999. Budidaya Bekicot. Penerbit Bharatara, Jakarta.

Aprianto, A., D. Ferdias, N.L. Puspitasari., Sedernawati, S. Budiyanto., 1989. Analisa Pangan, Bogor: Departemen pendidikan dan kebudayaan Direktorat Jendral Pendidikan Tinggi Pusat Antar Universitas Pangan dan Gizi Institut Pertanian Bogor.

Chey, T. T., 1977. Soy Sauce Fermentation: Microbial and Technology Development. Singapora Institut of Standard and Industrial Research, Singapura.

Dewi.,2011. Analisis Cemaran Logam Timbal

$(\mathrm{Pb})$, Tembaga $(\mathrm{Cu})$, dan Kadmium $(\mathrm{Cd})$ dalam Tepung Gandum secara Sprktrofotometri Serapan Atom. Skripsi. Jurusan Farmasi Fakultas MIPA UI. Jakarta.

Djajasewa,H., 1995. Pakan Ikan. CV Yasaguna, Jakarta.

Emma., 2006. Studi pembuatan pakan ikan. Skripsi. Politeknik Negeri Medan.

Furuichi,M., 1988. Dietary requirement, p.8-7.In Watanabe. Fish nutrition and mariculture. Departement of Aquatic Bioscience. Tokto University of Fisheries. JICA.

Ginting, S. P., Krisnan, R. 2006. Pengaruh Fermentasi Menggunakan Beberapa Strain Trichoderma dan Masa Inkubasi Berbeda terhadap Komposisi Kimiawi Bungkil Inti Sawit. Seminar Nasional Teknologi Peternakan dan Veteriner.
Loka Penelitian Kambing Potong, Galang.

Gusrina., 2008. Budidaya Ikan. Edisi kedua. Departement Pendidikan Nasional, Jakarta. www.ftp.lipi.go.id. 22 Oktober 2015. Hal 284.

Halver, J. E., 1989. Fish Nutrition. Academic Press, Inc. University of Wangshington Seatle, Washington.

Handojo, F.L., 1989. Budidaya Bekicot (Achatina fuluica). CV. Simplex. Jakarta.

Kamal, M., 1994. Nutrisi Ternak I. Fakultas Peternakan Universitas Gadjah Mada. Yogyakarta.

Millamena, Om, RM Coloso, and FP Pasual. 2002. Nutrition in tropical aquaculture. SEAFDEC. Tigbauanm lloilo, Philippines.

Mudjiman. A., 2004. Makanan Ikan. Penerbit Swadaya, Jakarta.

Murtidjo,B.A., 2001. Pedoman Meramu Pakan Ikan. Penerbit Kanisius, Yogyakarta.

Murphy, H., 2005. Pemanfaatan Kulit Buah Pisang untuk Produksi Enzim Selulase oleh Trichoderma viride. IPB: Bogor.

Prasetijo,B., 2010. Phylum Mollusca. Smart_ebook.

http://smart-pustaka.blogspot.com. Diakses tanggal 20 Mei 2015.

Richana, N., 2012. Ubi Kayu dan Ubi jalar. Penerbit Nusa indah, Bandung.

Raflie., 2007. Rancang Mesin Cetak Pelet. Skripsi. Politeknik Negeri Medan.

Sahwan,F.M., 2002. Pakan Ikan dan Udang. Penerbit Swadaya, Jakarta.

Santosa, B.H., 1989. Budidaya Bekicot. Penerbit Kanisius, Yogyakarta.

Saono, J.K.D. 1981. Mikroba of Ragi: Its Composition and as Source of Industrial Yeast. Di dalam: Proceeding of ASCA Technical Seminar, Medan.

Suprayudi, M. A., Edriani, G., Ekasari, J. 2012. Evaluasi Kualitas Produk Fermentasi Berbagai Bahan Baku Hasil Samping Agroindustri Lokal: Pengaruhnya Terhadap Kecernaan serta Kinerja Pertumbuhan Juvenil Ikan Mas. Jurnal Akuakultur Indonesia. 11 (1): 1 - 10 
Suprihatin. 2010. Teknologi Fermentasi. UNESA Press, Surabaya

SNI-01-2891-1992. Cara Uji Makanan dan Minuman. Badan Standardisasi Nasional.

Stickney,R.R dan R.T. Lovell., 1977. Nutrittion and Feeding of Channel Catfish. A Report from the Nutrition Subcommite og Regional Research Project S-83. Southern Cooperative Series, Bulletin 218.

Tacon., 1987. The Nutrition and Feeding Farmed
Fish and Shrimp A Training Manual Part I: The Essensial Nutriend. Brazilia: FAO of The UN.

Talib, C., 1999. Bekicot. Penerbit Nusa Indah, Jakarta.

Oboh, G. dan Elusiyan, C.A. (2007). Change in the nutrient and antinutrient content of micro-fungi fermented cassava flour produced from low and medium cyanide variety of cassava tuber. African Journal of Biotechnology 6(18): 2150-2157.

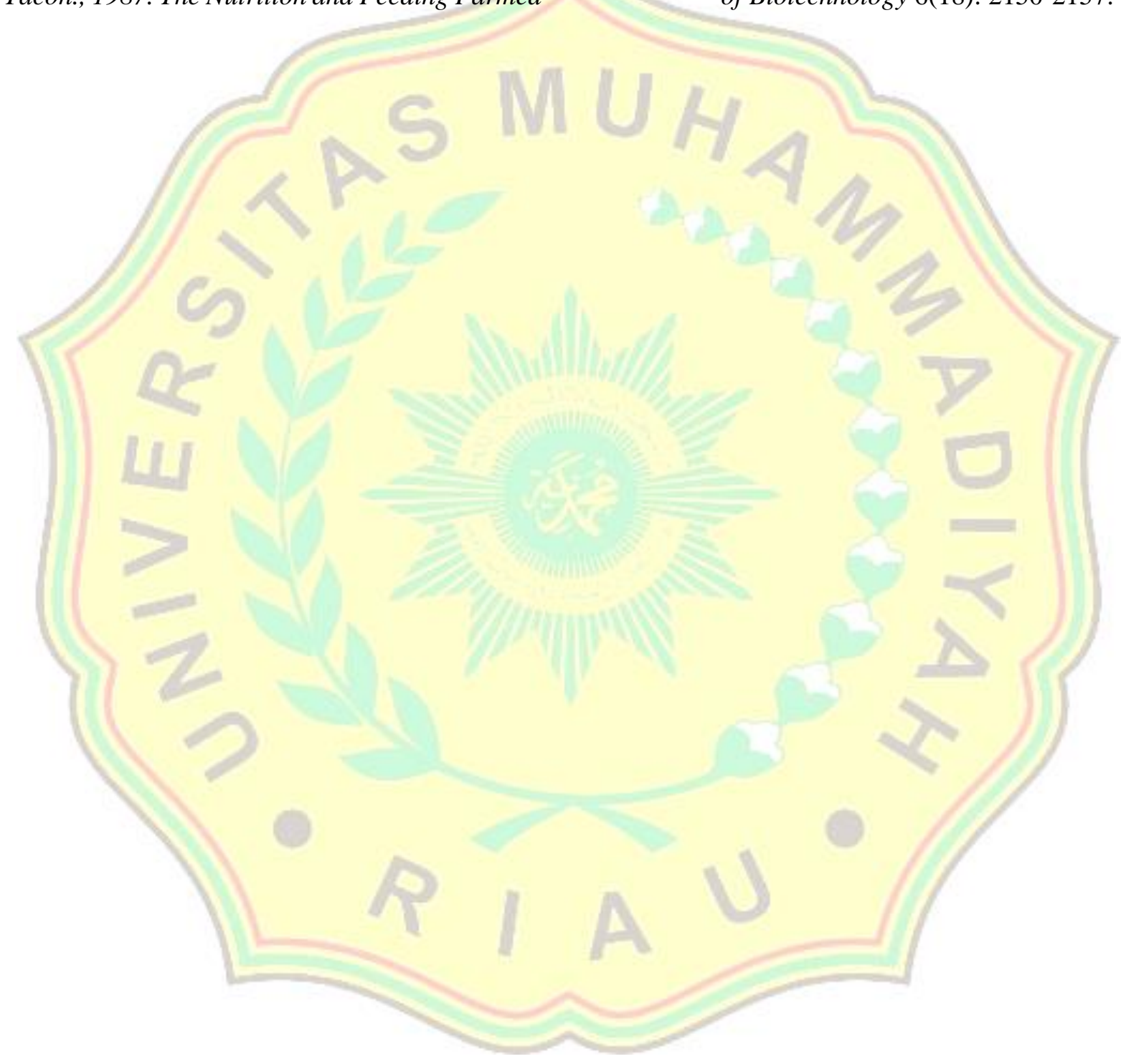

